\title{
PEMBERIAN MUT'AH DAN NAFKAH IDDAH DALAM PERKARA CERAI GUGAT
}

\author{
Heniyatun $^{1^{*}}$, Puji Sulistyaningsih ${ }^{2}$, Siti Anisah $^{3}$ \\ 1,2,3Ilmu Hukum/Fakultas, Hukum Universitas Muhammadiyah Magelang \\ E-Mail: *heniyatun@ummgl.ac.id
}

\begin{abstract}
Abstrak: Penelitian ini bertujuan untuk mengetahui bagaimana pertimbangan hukum hakim dalam pemberian mut'ah dan nafkah iddah dalam perkara cerai gugat dan bagaimana pelaksanaan isi putusan atas pemberian mut'ah dan nafkah iddah dalam perkara cerai gugat. Metode penelitian pustaka (library research) dengan menggunakan pendekatan kualitatif dan yuridis normatif yaitu penelitian hukum yang dilakukan dengan cara meneliti bahan pustaka atau data sekunder. Teknik pengelolahan data yang digunakan yaitu teknik analisis data deskriptifnormatif, dan penarikan kesimpulan dilakukan secara deduktif. Berdasarkan hasil penelitian dan pembahasan dapat disimpulkan bahwa: 1) Pertimbangan hukum hakim dalam pemberian mut'ah dan nafkah iddah dalam perkara cerai gugat nomor 0076/Pdt.G/2017/PA.Mgl yaitu mendasarkan pada Pasal 41 huruf (c) UU Nomor 1 Tahun 1974 jo Pasal 149 huruf (a) dan (b) KHI serta Yurisprudensi Mahkamah Nomor 137 K/AG/2007 tanggal 6 Februari 2008 dan Nomor 02 K/AG/2002 tanggal 6 Desember 2003. Putusan tersebut menyimpangi ketentuan Pasal 149 KHI, namun demikian pertimbangan hukum hakim dalam perkara tersebut mengandung terobosan hukum dengan metode penemuan hukum dan berpedoman pada Pasal 10 ayat (1) dan Pasal 5 ayat (1) UU Nomor 48 Tahun 2009 tentang Kekuasaan Kehakiman dalam memberikan putusan berkaitan dengan nusyuz, sehingga meskipun perceraian diajukan oleh isteri (cerai gugat) tetapi isteri tidak terbukti nusyuz maka secara ex officio suami dapat dihukum untuk memberikan nafkah iddah kepada bekas isterinya. Putusan hakim tersebut mengakodomasi pendapat madzhab Hanafi. Penerapan hak ex officio hakim tersebut juga menyimpangi ketentuan Pasal 178 ayat (3) HIR/ Pasal 189 ayat (3) RBG yang menyatakan bahwa hakim dilarang menjatuhkan keputusan atas perkara yang tidak dituntut, atau memberikan lebih daripada yang dituntut, namun demikian putusan tersebut tidak melanggar asas ultra petita. 2) Pelaksanaan isi putusan perkara nomor 0076/Pdt.G/2017/PA.Mgl adalah secara sukarela di luar persidangan, apabila tergugat tidak melaksanakan isi putusan secara sukarela maka penggugat dapat mengajukan permohonan eksekusi terhadap putusan tersebut dengan mengajukan permohonan eksekusi sejumlah uang. Kelemahan putusan ini yaitu tidak ada instrumen yang dapat memaksa tergugat untuk membayar mut'ah dan nafkah iddah yang telah diputuskan sebagaimana pada perkara cerai talak, instrumen pelaksanaan putusan dalam cerai talak dapat dilaksanakan melalui sidang ikrar talak.
\end{abstract}

Kata kunci: Cerai Gugat, Mut'ah dan Nafkah Iddah

\section{PENDAHULUAN}

Perkawinan tidaklah semata-mata sebagai hubungan atau kontrak perdata biasa, akan tetapi mempunyai nilai ibadah. Hal ini sesuai dengan rumusan Pasal 2 Inpres Nomor 1 Tahun1991 tentang Kompilasi Hukum Islam (KHI) menegaskan bahwa perkawinan adalah pernikahan, yaitu akad yang sangat kuat atau miitsaaqan gholiidhan untuk mentaati perintah Allah dan melaksanakannya merupakan ibadah. 
Demikian pula Pasal 1 Undang-Undang Nomor 1 Tahun 1974 tentang Perkawinan menyebutkan bahwa perkawinan adalah ikatan lahir batin antara seorang pria dengan seorang wanita sebagai suami istri dengan tujuan membentuk keluarga atau rumah tangga yang bahagia dan kekal berdasarkan Ketuhanan Yang Maha Esa. Berdasarkan kedua rumusan tersebut, dapat disimpulkan bahwa perkawinan merupakan sunnah Rasul SAW yang bertujuan untuk membentuk keluarga sakinah mawadah wa rahmah yang tidak lain hanya untuk beribadah kepada Allah SWT. Suami istri dalam suatu perkawinan mempunyai tanggung jawab secara vertikal kepada Tuhan Yang Maha Esa di samping mempunyai hak dan kewajiban secara timbal balik antara suami dan istri serta anak-anak yang lahir dalam perkawinan. Dalam pergaulan antara suami istri tidak jarang terjadi perselisihan dan pertengkaran yang terus menerus, maupun sebab-sebab lain yang kadangkadang menimbulkan suatu keadaan yang menyebabkan suatu perkawinan tidak dapat dipertahankan lagi, sedangkan upaya-upaya damai yang dilakukan oleh kedua belah pihak maupun keluarga tidak membawa hasil yang maksimal sehingga pada akhirnya jalan keluar yang harus ditempuh tidak lain adalah perceraian.

Pasal 39 ayat (1) UUPerkawinan memuat ketentuan imperatif bahwa perceraian hanya dapat dilakukan di depan sidang Pengadilan, setelah Pengadilan yang bersangkutan berusaha mendamaikan kedua belah pihak akan tetapi tidak berhasil. Perceraian yang dilakukan di depan sidang pengadilan juga harus ada alasan-alasan yang sah menurut undang-undang sebagaimana diatur dalam berikutnya yaitu ayat (2) yang menyebutkan bahwa, untuk melakukan perceraian harus ada cukup alasan bahwa antara suami istri itu tidak akan dapat rukun sebagai suami isteri. Adapun alasan-alasan perceraian tertuang dalam
Pasal 19 Peraturan Pemerintah Nomor 9 Tahun 1975 tentang Pelaksanaan UndangUndang Perkawinan (UU No. 1/1974) dan Pasal 116 KHI.

Selanjutnya berdasarkan KHI Pasal 149 dinyatakan bahwa akibat putusnya perkawinan karena talak, maka suaminya wajib :

a. Memberikan mut'ah yang layak kepada bekas isterinya, baik berupa uang atau benda, kecuali bekas isteri tersebut Qabla ad dukhul.

b. Memberikan nafkah, maskan (tempat tinggal) dan kiswah (pakaian) kepada bekas isteri selama masa iddah, kecuali bekas isteri telah dijatuhi talak bain atau nusyuz dan dalam keadaan tidak hamil.

c. Melunasi mahar yang masih tehutang seluruhnya, atau separo bila qabla ad dukhul.

d. Memberikan biaya hadanah untuk anak-anaknya yang belum mencapai umur 21 tahun.

Akibat hukum dari putusnya perkawinan karena perceraian juga diatur dalam Pasal 41 Undang-Undang Nomor 1 Tahun 1974 yaitu :

a. Baik ibu atau bapak berkewajiban memelihara dan mendidik anakanak, semata-mata berdasarkan kepentingan anak, bilamana ada perselisihan mengenai penguasaan anak-anak, pengadilan memberi keputusannya.

b. Bapak yang bertanggung jawab atas semua biaya pemeliharaan dan pendidikan yang diperlukan anak itu, bilamana bapak dalam kenyataanya tidak dapat memenuhi kewajiban tersebut, pengadilan dapat menentukan bahwa ibu memikul biaya tersebut.

c. Pengadilan dapat mewajibkan kepada bekas suami untuk memberikan biaya penghidupan dan/atau menetukan suatu kewajiban bagi bekas istri. 
Apabila dicermati dari kedua ketentuan tersebut terdapat perbedaan. Di dalam Pasal 41 UU No. 1 Tahun 1974 mengatur akibat putusnya perkawinan karena perceraian baik cerai talak maupun cerai gugat, sedangkan Pasal $149 \mathrm{KHI}$ mengatur tentang akibat hukum perceraian yang diajukan oleh suami (cerai talak) saja. Berdasarkan ketentuan Pasal $149 \mathrm{KHI}$ bahwa dalam perkara cerai gugat pada umumnya hakim tidak menghukum suami untuk memberikan mut'ah dan nafkah iddah. Namun demikian dalam putusan Pengadilan Agama Magelang Nomor Perkara 0076/Pdt.G/2017/ PA.Mgl. tanggal 15 Juni 2017 yang telah berkekuatan hukum tetap dalam perkara cerai gugat hakim memberi putusan secara ex officio mengabulkan gugatan cerai penggugat dan menjatuhkan talak satu ba'in sughra tergugat terhadap penggugat dengan membebankan mut'ah dan nafkah iddah kepada tergugat/ mantan suami meskipun dalam perkara cerai gugat tersebut penggugat (isteri) tidak menuntut nafkah iddah dan mut'ah.

Putusan perkara nomor 0076/ Pdt.G/2017/PA.Mgl tersebut terkesan menyimpangi ketentuan Pasal 178 ayat (3) HIR (Herzien Inlandsch Reglement)/ Pasal 189 ayat (3) RBG (Rechtreglement voor de Buitengewesten) bahwa hakim dilarang menjatuhkan keputusan atas perkara yang tidak dituntut, atau memberikan lebih daripada yang dituntut. Akan tetapi jika dilihat dalam ketentuan Pasal 10 ayat (1) Undang-Undang Nomor 48 Tahun 2009 tentang Kekuasaan Kehakiman bahwa "Pengadilan dilarang menolak untuk memeriksa, mengadili, dan memutus suatu perkara yang diajukan dengan dalih bahwa hukum tidak ada atau kurang jelas, melainkan wajib memeriksa dan mengadilinya". Berdasarkan hal tersebut maka hakim wajib menggali, mengikuti dan memahami nilai-nilai hukum dan rasa keadilan yang hidup dalam masyarakat. Dengan kata lain, hakim harus melakukan penemuan hukum (rechtsvinding) sebagaimana berpedoman pada Pasal 5 ayat (1) UU No. 48 Tahun 2009. Hanya persoalan yang kemudian timbul apakah Pasal 178 ayat (3) HIR/ Pasal 189 ayat (3) dapat disimpangi dalam penerapannya.

Berdasarkan urian di atas menarik untuk diteliti tentang hak-hak isteri akibat cerai gugat dan pertimbangan hukum hakim dalam memutuskan secara ex officio terkait pemberian mut'ah dan nafkah iddah dalam perkara cerai gugat dengan menganalisis putusan perkara cerai gugat Nomor 0076/Pdt.G/2017/PA.Mgl. Rumusan Masalah dalam penelitian ini yaitu:

1. Bagaimana pertimbangan hukum hakim dalam pemberian mut'ah dan nafkah iddah dalam perkara cerai gugat?

2. Bagaimana pelaksanaan isi putusan atas pemberian mut'ah dan nafkah iddah dalam perkara cerai gugat?

\section{METODE PENELITIAN}

Penelitian ini merupakan penelitian pustaka (library research) yaitu dengan cara mengambil dan mengumpulkan data dari literatur yang berhubungan dengan masalah yang dibahas yaitu tentang pemberian mut'ah dan nafkah iddah dalam perkara cerai gugat, penulis menggunakan pendekatan kualitatif. Penelitian kualitatif yaitu penelitian yang menghasilkan deskripsi berupa kata-kata atau lisan dari fenomena yang diteliti atau dari orang-orang yang berkompeten di bidangnya. $^{1}$ Jenis penelitian ini adalah penelitian yuridis normatif, yaitu penelitian hukum yang dilakukan dengan cara meneliti bahan pustaka atau data sekunderbelaka. ${ }^{2}$ Penelitianinidifokuskan untuk mengkaji penerapan kaidah

1 Lexy J Moeleong. 2001. Metodelogi Penelitian Kualitatif. Bandung : Rosda Karya. Hal. 3.

2 Soerjono Soekanto dan Sri Mamudji. 2013. Penelitian Hukum Normatif. Cetakan ke-15. Jakarta : Raja Grafindo Persada. Hal. 13. 
hukum positif dalam hal pertimbangan hukum hakim dalam memutus perkara secara ex officio menghukum suami (tergugat) untuk membayar mut'ah dan nafkah iddah pada perkara cerai gugat dengan menggunakan tiga pendekatan masalah yaitu pendekatan perundangundangan (statute approach), pendekatan konseptual (conceptual approach), dan pendekatan kasus (case approach). ${ }^{3}$ Teknik pengambilan data dalam penelitian ini menggunakan metode studi kepustakaan (library reasearch) dan metode studi lapangan (field research) dengan menggunakan metode wawancara atau interview. Teknik pengolahan data dalam penelitian ini menggunakan teknik analisis data deskriptif normatif, dan penarikan kesimpulan dilakukan secara deduktif. (Muthoifin, 2019)

\section{HASIL DAN PEMBAHASAN}

\section{Putusnya Perkawinan atau Perceraian}

Pada dasarnya perkawinan dilakukan untuk selama-lamanya sampai matinya salah satu suami istri. Dalam keadaan tertentu terdapat hal-hal yang mengakibatkan putusnya perkawinan, dalam arti bila perkawinan tetap dilanjutkan maka kemadharatan akan terjadi dalam hal ini, Islam membolehkan putusnya perkawinan sebagai langkah terakhir dari usaha melanjutkan rumah tangga sebagai suami istri. Ada beberapa bentuk putusnya perkawinan dari segi siapa yang berkehendak untuk putusnya perkawinan itu, yaitu sebagai berikut (Amir Syarifuddin, 2006:197) :

a) Putusnya perkawinan atas kehendak Allah sendiri melalui matinya salah satu suami istri. Dengan kematian itu dengan sendirinya berakhir hubungan perkawinan tersebut.

b) Putusnya perkawinan atas kehendak suami dengan berbagai alasan dinyatakan dengan ucapan tertentu.

3 Peter Mahmud Marzuki. 2009. Penelitian Hukum. Jakarta : Kencana. Hal. 93.
Perceraian dalam hal ini disebut dengan talak.

c) Putusnya perkawinan atas kehendak istri karena melihat sesuatu yang mengakibatkan putusnya perkawinan, sedangkan suami tidak berkehendak atas itu. Kehendak putusnya perkawinan yang disampaikan istri dengan cara tertentu diterima oleh suami dan dilanjutkan dengan ucapan menjatuhkan talak untuk memutuskan perkawinan itu, putusnya perkawinan semacam itu disebut dengan khuluk.

d) Putusnya perkawinan atas kehendak hakim sebagai pihak ketiga setelah melihat adanya sesuatu pada suami dan/ istri yang menandakan tidak dapatnya hubungan perkawinan dilanjutkan.

Menurut Buya Hamka (1994:212), cerai dalam bahasa 'Arab di sebut "Ath-tholaaq" itu mengandung arti memutuskan atau meninggalkan. Menurut istilah, cerai adalah melepaskan ikatan perkawinan dan mengakhiri hubungan suami isteri. Talak artinya ialah lepas atau putus pertalian, habis pergaulan, bercerai, dan berpisah. Di dalam Islam, pada prinsipnya perceraian itu dilarang, kecuali ada alasan-alasan objektif yang menuntut adanya sebuah perceraian antara suami isteri. Dari Ibn 'Umar r.a., ia telah menyampaikan, Rasulullah SAW telah bersabda:

“Telah menceritakan kepada kami Katsir bin Ubaid Al-Himsi berkata, telah menceritakan kepada kami Muhammad bin Khalid dari Ubaidullah bin Al- Walid Al-Washshafi dari Muharib bin Ditsar dari Abdullah bin Umar ia berkata, Rasulullah shallallahu 'alaihi wasallam bersabda: Perkara halal yang paling di benci oleh Allah adalah perceraian". (Hadits Riwayat Ibnu Majah).

Berdasarkan UU No. 1 Tahun 1974 tentang Perkawinan (UUPerkawinan) 
sebagaimana tersurat pada Pasal 1, tujuan dari perkawinan adalah untuk membentuk keluarga (rumah tangga) yang bahagia dan kekal berdasarkan ketentuan Tuhan Yang Maha Esa. Dua kata kunci tampak dalam UndangUndang ini yaitu bahagia dan kekal. Bahagia maksudnya bahwa perkawinan menghendaki kebahagiaan lahir dan batin pelakunya yang diakibatkan adanya penyaluran hasrat seksual yang aman dan dibolehkan. Kekal maksudnya bahwa pernikahan diorientasikan untuk sepanjang hidup dan menghindari perceraian. Merujuk pada ketentuan tersebut, maka dapat dikatakan perceraian adalah putusnya ikatan lahir batin antara suami dan istri yang mengakibatkan berakhirnya hubungan keluarga (rumah tangga) antara suami dan istri tersebut.

Pasal 38 Undang-Undang Perkawinan menyebutkan bahwa perceraian hanyalah satu sebab dari putusnya perkawinan, karena putusnya perkawinan dapat terjadi karena Kematian; Perceraian; dan atas keputusan Pengadilan.

\section{Syarat dan Alasan Perceraian}

Undang-undang tidak memperbolehkan perceraian dengan mufakat saja atau antara suami dan isteri, tetapi perceraian harus dilakukan di depan pengadilan dan perceraian harus ada alasan-alasan yang sah. Hal ini sebagaimana diatur dalam Pasal 39 UU Perkawinan tentang syarat-syarat perceraian yitu:

1) Perceraian hanya dapat dilakukan di depan sidang pengadilan setelah pengadilan yang bersangkutan berusaha dan tidak berhasil mendamaikan kedua belah pihak;

2) Untuk melakukan perceraian harus ada cukup alasan, bahwa antara suami-istri itu tidak akan dapat hidup rukun sebagai suami-istri;

3) Tata cara perceraian di depan sidang pengadilan diatur dalam peraturan perundang-undangan tersendiri.
Pengadilan yang dimaksud dalam hal ini adalah Pengadilan Agama bagi orang yang beragama Islam dan Pengadilan Umum bagi orang selain Islam. Peradilan Agama merupakan salah satu pelaksana kekuasaan kehakiman di Indonesia yang berada di bawah naungan Mahkamah Agung sejalan dengan tiga lingkungan peradilan lain, yaitu Peradilan Umum, Peradilan Militer, dan Peradilan Tata Usaha Negara. Kedudukan Peradilan Agama sebagaimana tertuang dalam Pasal 49 Undang-Undang Nomor 7 Tahun 1989 tentang Peradilan Agama yang telah diubah dengan Undang-Undang Nomor 3 Tahun 2006 dan Perubahan Kedua dengan Undang-Undang Nomor 50 Tahun 2009, Pengadilan Agama bertugas dan berwenang memeriksa, memutus, dan menyelesaikan perkara di tingkat pertama antara orang-orang yang beragama Islam di bidang : 1) Perkawinan; 2) Waris; 3) Wasiat; 4) Hibah; 5) Wakaf; 6) Zakat; 7) Infak; 8) Sedekah; dan 9) Ekonomi Syariah. Perkara di bidang perkawinan sendiri, dalam penjelasan Pasal 49 mencakup setidaknya 22 bidang hukum, di antaranya mengenai perceraian karena talak dan gugatan perceraian.

Alasan-alasan yang dapat dijadikan dasar untuk melakukan perceraian diatur dalam Kompilasi Hukum Islam (KHI) Pasal 116, bahwa Perceraian dapat terjadi karena :

a) Salah satu pihak berbuat zina atau menjadi pemabuk, pemadat, penjudi dan lain sebagainya yang sukar disembuhkan;

b) Salah satu pihak meninggalkan pihak lain selama 2 (dua) tahun berturutturut tanpa izin pihak lain dan tanpa alasan yang sah atau karena hal lain diluar kemampuannya;

c) Salah satu pihak mendapat hukuman penjara 5 (lima) tahun atau hukuman yang lebih berat setelah perkawinan berlangsung;

d) Salah satu pihak melakukan 
kekejaman atau penganiayaan berat yang membahayakan pihak lain;

e) Salah satu pihak mendapat cacat badan atau penyakit dengan akibat tidak dapat menjalankan kewajibannya sebagai suami atau isteri;

f) Antara suami dan isteri terus menerus terjadi perselisihan dan pertengkaran dan tidak ada harapan akan hidup rukun lagi dalam rumah tangga;

g) Suami melanggar taklik talak;

h) Peralihan agama atau murtad yang menyebabkan terjadinya ketidak rukunan dalam rumah tangga.

Alasan-alasan perceraian juga diatur pada Pasal 19 Peraturan Pemerintah Nomor 9 Tahun 1975 tentang Pelaksanaan Undang-Undang Perkawinan, yang menyatakan bahwa:

a) Salah satu pihak berbuat zina atau menjadi pemabuk, pemadat, penjudi, dan lain sebagainya yang sukar disembuhkan;

b) Salah satu pihak meninggalkan pihak lain selama 2 (dua) tahun berturutturut tanpa izin pihak lain dan tanpa alasan yang sah atau karena hal lain di luar kemampuannya;

c) Salah satu pihak mendapat hukuman penjara 5 (lima) tahun atau hukuman yang lebih berat setelah perkawinan berlangsung;

d) Salah satu pihak melakukan kekejaman atau penganiayaan berat yang membahayakan pihak yang lain;

e) Salah satu pihak mendapat cacat badan atau penyakit dengan akibat tidak dapat menjalankan kewajibannya sebagai suami/istri;

f) Antara suami dan istri terus-menerus terjadi perselisihan dan pertengkaran dan tidak ada harapan akan hidup rukun lagi dalam rumah tangga.
Dalam gugatan perceraian karena alasan tersebut dalam Pasal 116 huruf b (salah satu pihak meninggalkan pihak lain selama 2 (dua) tahun berturut-turut tanpa izin pihak lain dan tanpa alasan yang sah atau karena hal lain diluar kemampuannya), dapat diajukan setelah lampau 2 (dua) tahun terhitung sejak tergugat meninggalkan rumah (Pasal 33 KHI). Gugatan dapat diterima apabila tergugat menyatakan atau menunjukan sikap tidak mau lagi kembali ke rumah kediaman bersama. Selanjutnya, gugatan perceraian karena alasan tersebut dalam Pasal 116 huruf $\mathrm{f}$ (Antara suami dan istri terus menerus terjadi perselisihan dan pertengkaran dan tidak ada harapan akan hidup rukun lagi dalam rumah tangga), dapat diterima apabila telah cukup jelas bagi Pengadilan Agama mengenai sebabsebab perselisihan dan pertengkaran tu dan setelah mendengar pihak keluarga serta orang-orang yang dekat dengan suami istri tersebut (Pasal $34 \mathrm{KHI}$ ).

\section{Jenis-jenis Perceraian}

Jenis-jenis perceraian dapat dilihat berdasarkan siapa yang mengajukan perceraian, perceraian yang diajukan oleh suami atau isteri akan mempunyai akibat hukum yang berbeda. Jenis perceraian juga dapat ditinjau dari segi boleh tidaknya suami dan isteri rujuk kembali, dan perceraian juga dapat ditinjau dari segi waktu menjatuhkan talaknya. Berikut ini mengenai jenis-jenis perceraian:

1) Perceraian ditinjau dari pihak yang mengajukan

a) Cerai Talak Menurut Pasal 114 KHI putusnya perkawinan yang disebabkan karena perceraian dapat terjadi karena talak atau berdasarkan gugatan perceraian. Pasal117 KHI menjelaskan bahwa talak adalah 
ikrar suami di hadapan sidang Pengadilan Agama yang menjadi salah satu sebab putusnya perkawinan. Berdasarkan Buku II Edisi Revisi Tahun 2013, Pedoman Pelaksanaan Tugas dan Administrasi Peradilan Agama (2014:147) cerai talak diajukan oleh pihak suami yang petitumnya memohon untuk diizinkan menjatuhkan talak terhadap isterinya. Dalam ketentuan perundang-undangan tersebut dapat dipahami bahwa cerai talak adalah permohonan cerai yang diajukan oleh suami.

b) Cerai Gugat

Berdasarkan Pasal 114 KHI di atas, bahwa gugatan perceraian adalah pengajuan perceraian yang diajukan oleh isteri. Buku II edisi Revisi Tahun 2013 tentang Pedoman Pelaksanaan Tugas dan Administrasi Peradilan Agama (2014:149) menyebutkan bahwa Cerai gugat adalah cerai yang diajukan oleh isteri yang petitumnya memohon agar Pengadilan Agama/ Mahkamah Syari'ah memutuskan perkawinan penggugat (isteri) dengan tergugat (suami). Dalam Hukum Islam disebut khuluk, sebagaimana disebutkan dalam Pasal 1 huruf (i) KHI bahwa Khuluk adalah perceraian yang terjadi atas permintaan isteri dengan memberikan tebusan atau iwadl kepada dan atas persetujuan suaminya. Proses penyelesaian gugatan tersebut dilakukan sesuai dengan prosedur cerai gugat dan harus diputus oleh hakim (Ibid, 2014: 151).

Di Indonesia khuluk biasanya dikaitkan dengan pelanggaran taklik talak. Taklik talak menurut ketentuan Pasal 1 huruf (e) Kompilasi Hukum Islam (KHI) adalah perjanjian yang diucapkan calon mempelai pria setelah akad nikah yang dicantumkan dalam Akta Nikah berupa janji talak yang digantungkan kepada suatu keadaan tertentu yang mungkin terjadi dimasa yang akan datang. Inti perjanjian itu adalah persetujuan suami untuk menjatuhkan talaknya apabila taklik talak (janji) yang telah diucapkan oleh suami sesaat setelah akad nikah sebagaimana tersebut dalam buku nikah itu dilanggar oleh pihak suami. Suami bersedia menerima gugatan cerai (khuluk) yang diajukan oleh isteri ketika suami melakukan pelanggaran seperti yang telah disebutkan. Sehingga pada hakekatnya, sighat taklik talak ini adalah janji dari suami untuk mengabulkan khuluk isterinya, ketika suami melakukan pelanggaran sebagaimana yang disebutkan dalam buku nikah.

2) Perceraian ditinjau dari segi boleh tidaknya suami merujuk istrinya kembali

a) Talak Raj'i

Pasal 118 KHI menjelaskan bahwa Talak Raj i adalah talak kesatu atau kedua, di mana suami berhak rujuk selama isteri dalam masa iddah. Setelah talak raj'i maka isteri wajib ber-iddah, hanya bila kemudian suami hendak kembali kepada bekas isteri sebelum berakhir masa iddah, maka hal ini dapat dilakukan dengan menyatakan rujuk, tetapi jika dalam masa iddah tersebut bekas suami tidak menyatakan rujuk terhadap bekas isterinya, maka dengan berakhirnya 
masa iddah itu kedudukan talak menjadi talak $b a^{\prime}$ in, kemudian jika sesudah berakhirnya masa iddah itu suami ingin kembali kepada bekas isterinya maka wajib dilakukan dengan akad nikah baru, dan dengan mahar yang baru pula. Tidak dibenarkan bekas suami mempergunakan hak merujuk itu dengan tujuan yang tidak baik, misalnya untuk menyengsarakan bekas isterinya, atau untuk mempermainkannya, sebab dengan demikian bekas suami itu berbuat aniaya atau berbuat dzalim (Qs. Al Baqarah ayat 231 ).

b) Talak Ba'in Shughra

Pasal 119 ayat (1) KHI menjelaskan bahwa Talak Ba in Shughra adalah talak yang tidak boleh dirujuk tapi boleh akad nikah baru dengan bekas suaminya meskipun dalam iddah. Talak yang dijatuhkan oleh Pengadilan Agama.

c) Talak Ba'in Kubra

Pasal 120 KHI menyebutkan bahwa Talak Ba in Kubraa adalah talak yang terjadi untuk ketiga kalinya. Talak jenis ini tidak dapat dirujuk dan tidak dapat dinikahkan kembali, kecuali apabila pernikahan itu dilakukan setelah bekas isteri, menikah dengan orang lain dan kemudian terjadi perceraian, serta telah selesai masa iddahnya.

3) Talak ditinjau dari segi waktu menjatuhkan talaknya

\section{a) Talak Sunni}

Pasal 121 KHI menjelaskan bahwa talak sunni adalah talak yang dibolehkan yaitu talak yang dijatuhkan terhadap isteri yang sedang suci dan tidak dicampuri dalam waktu suci tersebut. b) Talak Bid'i

Berdasarkan Pasal 122 KHI menjelaskan bahwa Talak bid $i$ adalah talak yang dilarang, yaitu talak yang dijatuhkan pada waktu isteri dalam keadaan haid atau isteri dalam keadaan suci tapi sudah dicampuri pada waktu suci tersebut.

c) Talak La Sunni Wala Bid'i

Talak La Sunni Wala Bid'i yaitu talak yang dijatuhkan terhadap isteri yang belum pernah digauli. Talak yang dijatuhkan terhadap isteri yang belum pernah haid, atau isteri yang telah lepas haid. Talak yang dijatuhkan terhadap isteri yang sedang hamil.

\section{Akibat Hukum Perceraian}

Akibat putusannya perkawinan karena perceraian berdasarkan Pasal 41 Undang-Undang Perkawinan ialah :

1) Baik ibu atau bapak berkewajiban tetap memelihara dan mendidik anakanaknya, semata-mata berdasarkan kepentingan anak bilamana ada perselisihan mengenai penguasaan anak-anak pengadilan memberi putusannya.

2) Ayah yang bertanggung jawab atas semua biaya-biaya pemeliharaan dan pendidikan yang diperlukan anak bilamana bapak dalam kenyataannya tidak dapat memenuhi kewajiban tersebut. Pengadilan dapat menentukan bahwa ibu ikut memikul biaya tersebut.

3) Pengadilan dapat mewajibkan kepada bekas suami untuk memberikan biaya-biaya penghidupan atau menentukan sesuatu kewajiban bagi bekas isteri.

Akibat hukum dari perceraian berdasarkan Kompilasi Hukum Islam (KHI) pasal 149 menyatakan bahwa akibat 
putusnya perkawinan karena talak, maka suaminya wajib :

1) Memberikan mut'ah yang layak kepada bekas isterinya, baik berupa uang atau benda, kecuali bekas isteri tersebut Qabla ad dukhul.

2) Memberikan nafkah, maskan (tempat tinggal) dan kiswah (pakaian) kepada bekas isteri selama masa 'iddah, kecuali bekas isteri telah dijatuhi talak $b a^{\prime}$ in atau nusyuz dan dalam keadaan tidak hamil.

3) Melunasi mahar yang masih tehutang seluruhnya, atau separo bila qabla ad dukhul.

4) Memberikan biaya hadanah untuk anak-anaknya yang belum mencapai umur 21 tahun.

Selanjutnya, akibat putusnya perkawinan berdasarkan Pasal 156 Kompilasi Hukum Islam bahwa :

1) Pemeliharaan anak yang belum mumayyiz atau belum berumur 12 tahun adalah hak ibunya.

2) Pemeliharaan anak yang sudah mumayyiz diserahkan kepada anak untuk memilih diantara ayahnya atau ibunya sebagai pemegang hak pemeliharaannya.

3) Biaya pemeliharaan ditanggung oleh ayahnya.

Berdasarkan uraian di atas dapat disimpulkan bahwa, akibat dari putusnya perkawinan karena perceraian berdasarkan hukum positif adalah berkaitan dengan hak-hak mantan isteri yaitu nafkah iddah, nafkah mut'ah, nafkah madliyah, dan mahar terutang, hak asuh dan pemeliharaan anak, serta harta bersama.

\section{Mut'ah}

Menurut Abdul Aziz Muhammad Azzam dan Abdul Wahhab Sayyed Hawwas (2009:207) mut'ah dengan dhomah mim (Mut'ah) atau kasrah (mit'ah) akar kata dari Al Mata, yaitu sesuatu yang disenangi. Maksudnya, materi yang diserahkan suami kepada istri yang dipisahkan dari kehidupan sebab talak atau semakna dengan beberapa syarat.

Menurut pendapat Muhammad Baqir (2016:301-302), pemberian mut'ah ini adalah sebagai pelaksanaan perintah Allah Swt kepada para suami agar selalu mempergauli istri-istri mereka dengan prinsip imsak bi maeruf au tasrih bi ihsan (yaitu mempertahankan ikatan perkawinan dengan kebaikan atau melepaskan (menceraikan) dengan kebajikan. Oleh karena itu, kalaupun hubungan perkawinan terpaksa diputuskan, perlakuan baik harus tetap dijaga, hubungan baik pun dengan mantan istri dan keluarganya sedapat mungkin dipertahankan, disamping melaksanakan pemberian mut'ah dengan ikhlas dan sopan santun tanpa sedikitpun menunjukan kegusaran hati, apalagi penghinaan dan pencelaan.(Muthoifin \& Rahman, 2019)

Kesimpulanya Mut'ah adalah pemberian bekas suami kepada mantan isteri, yang dijatuhi talak berupa benda atau uang dan lainnya untuk menjaga hubungan baik dengan mantan isteri dan keluarga, sekalipun perkawinan tidak dapat dipertahankan namun melepasnya (menceraikannya) dengan kebaikan.

Mut'ah diatur pada Pasal 149 huruf (a), Pasal 158, Pasal 159 dan Pasal 160 KHI. Pasal 149 huruf (a) menyebutkan bahwa bilamana perkawinan putus karena talak, maka bekas suami wajib memberikan mut'ah yang layak kepada bekas isterinya, baik berupa uang atau benda, kecuali bekas isteri tersebut qobla ad dukhul. Qabla ad dukhul artinya belum berlangsung hubungan seksual antara keduanya. Syarat pemberian mut'ah yaitu (Pasal 158) :

1) Belum ditetapkan mahar bagi isteri ba'da al dukhul;

2) Perceraian itu atas kehendak suami. 
Adapun Pasal 159 KHI menyebutkan bahwa mut'ah sunat diberikan oleh bekas suami tanpa syarat tersebut pada Pasal 158. Dari ketentuan di atas dipahami bahwa pemberian mut'ah dapat menjadi wajib dan dapat menjadi sunat. Mut'ah wajib diberikan oleh bekas suami dengan syarat belum ditetapkan mahar bagi isteri ba'da ad dukhul (telah terjadi hubungan seksual antara keduanya) dan perceraian atas kehendak suami. Namun demikian meskipun ketentuan Pasal 158 tidak terpenuhi, bekas suami sunat memberikan mut'ah kepada mantan isteri. Artinya meskipun mahar telah ditetapkan bagi isteri ba'da ad dukhul dan perceraian atas kehendak isteri bukan atas kehendak suami, suami boleh memberikan mut'ah kepada isteri dan seyogyanya suami memberikan mut'ah kepada mantan isteri sebagai obat penghibur hati mantan isteri akibat dari perceraian. Pemberian mut'ah merupakan suatu perbuatan baik yang disyariatkan (disunnatkan) oleh Islam mengingat betapa besar pengorbanan dan pengabdian isteri selama masa perkawinan. Besar kecilnya mut'ah yang diberikan mantan suami kepada mantan isteri berpedoman pada Pasal $160 \mathrm{KHI}$ yang menyebutkan bahwa besarnya mut'ah diberikan sesuai dengan kepatutan dan kemampuan suami dengan mempertimbangkan pula perceraian itu adalah atas kehendak suami, dan isteri telah mendampingi dan mengabdi terhadap suami selama masa perkawinan yang cukup lama.

Selain KHI, mut'ah juga diatur dalam Keputusan Ketua Mahkamah Agung RI Nomor : KMA/032/SK/IV/2006 tentang Pemberlakuan Buku II Pedoman Pelaksanaan Tugas dan Administrasi Peradilan Agama Edisi Revisi Tahun 2013 (2014:148) menyebutkan bahwa dalam perkara cerai talak :

1) Pengadilan Agama/ Mahkamah Syar'iyah secara ex officio dapat menetapkan kewajiban nafkah iddah atas suami untuk isterinya, sepanjang isterinya tidak terbukti berbuat nusyuz, dan menetapkan kewajiban mut'ah (Pasal 41 huruf (c) UU No. 1 Tahun 1974 jo Pasal 149 huruf (a) dan (b) KHI.

2) Dalam pemeriksaan cerai talak, Pengadilan Agama/ Mahkamah Syar'iyah sedapat mungkin berupaya untuk mengetahui jenis pekerjaan dan pendidikan suami yang jelas dan pasti dan mengetahui perkiraan pendapatan rata-rata perbulan untuk dijadikan dasar pertimbangan dalam menetapkan nafkah madhiyah, nafkah iddah dan nafkah anak.

3) Agar memenuhi asas manfaat dan mudah dalam pelaksanaan putusan, penetapan mut'ah sebaiknya berupa benda bukan uang, misalnya rumah, tanah atau benda lainnya, agar tidak menyulitkan dalam eksekusi. Mut'ah wajib diberikan oleh bekas suami dengan syarat belum ditetapkan mahar bagi isteri ba'da dukhul dan perceraian atas kehendak suami. Besarnya mut'ah disesuaikan dengan kepatutan dan kemampuan suami (Pasal 158 dan 160 KHI). Berdasar ketentuan tersebut, dapat dipahami bahwa kewajiban suami memberikan mut'ah adalah akibat dari perceraian yang diajukan oleh suami atau cerai talak, sedangkan apabila perceraian diajukan oleh isteri atau cerai gugat kewajiban pemberian mut'ah tersebut tidak diatur.

Pemberian mut'ah dalam hukum Islam juga secara tegas diatur dengan menekankan sebagai kewajiban suami, sebagaimana pendapat $\mathrm{Abu}$ Hanifah yang dikemukakan oleh Ibnu Rusyd (2007:621-622) bahwa mut'ah diwajibkan untuk setiap wanita yang dicerai sebelum digauli, sedang suami belum menentukan maskawin untuknya. Demikian pula Imam Syafi'i berpendapat bahwa mut'ah 
diwajibkan untuk setiap istri yang dicerai manakala pemutusan perkawinan datang dari pihak suami, kecuali istri yang telah ditentukan maskawin untuknya dan dicerai sebelum digauli. Jumhur ulama juga memegang pendapat ini. Abu Hanifah beralasan dengan firman Allah Swt QS. Al Ahzab ayat 49 yang artinya: "Hai orang-orang yang beriman, apabila kamu menikahi perempuan-perempuan yang beriman, kemudian kamu ceraikan mereka sebelum kamu atas mereka iddah bagimu yang kamu minta menyempurnakannya. Maka berilah mereka mut'ah dan lepaskanlah mereka itu dengan cara yang sebaik- baiknya".

Disamping itu, pendapat terakhir beberapa tokoh sahabat seperti Ali dan Umar serta kedua putra mereka Al-Hasan bin Ali dan Abdullah bin Umar r.a. yang dinilai shahih, sesuai dengan firman Allah Swt dalam Al-Qur'an Surah Al-Baqarah ayat 241: Artinya: "Kepada wanita-wanita yang dicerai talak, (baginya ada hak yang menjadi kewajiban suaminya) berupa mut'ah menurut yang ma'ruf sebagai suatu kewajiban bagi orang-orang yang bertaqwa".

Ukuran Mut'ah tidak diterangkan dalam syara', mut'ah berada diantara sesuatu yang memerlukan ijtihad maka wajib dikembalikan kepada hakim sebagaimana hal-hal lain yang memerlukan tempat. Mut'ah yang layak dan rasional pada suatu zaman terkadang tidak layak pada zaman lain. Demikian juga mut'ah yang layak di suatu tempat terkadang tidak layak ditempat lain. Ulama Sya'fiiyah berpendapat bahwa mut'ah tidak memiliki ukuran tertentu, tetapi disunahkan tidak kurang dari 30 dirham atau seharga dengan itu. Kewajibannya tidak melebihi dari mahar mitsil dan sunnahnya tidak melebihi dari separuh mahar mitsil. Dalam pendapat kuat ini dijelaskan bahwa hakim ketika berijtihad tentang ukuran mut'ah hendaknya melihat kondisi suami, apakah tergolong mudah atau susah, kaya atau miskin. Hal ini sebagaimana Firman Allah dalam QS. Al-Baqarah ayat 236 yang artinya: "Dan Hendaklah kamu berikan suatu mut'ah (pemberian) kepada mereka. Orang yang mampu menurut kemampuannya dan orang yang miskin menurut kemampuannya (pula).

\section{Nafkah Iddah}

Kewajiban suami memberikan nafkah iddah kepada istri yang diceraikannya merujuk pada Pasal 149 huruf (b) KHI menyatakan bahwa akibat putusnya perkawinan karena talak, maka suaminya wajib memberikan nafkah, maskan (tempat tinggal) dan kiswah (pakaian) kepada bekas isteri selama masa iddah, kecuali bekas isteri telah dijatuhi talak ba'in atau nusyuz dan dalam keadaan tidak hamil. Senada dengan Ketentuan Pasal 149 KHI, berdasarkan Keputusan Ketua Mahkamah Agung Republik Indonesia Nomor: KMA/032/SK/IV/2006 (2014:151) mengatur tentang penetapan kewajiban nafkah iddah terhadap suami dalam perkara cerai gugat, menyebutkan bahwa:

a) Pengadilan Agama/ Mahkamah Syar'iyah secara ex officio dapat menetapkan kewajiban nafkah iddah terhadap suami, sepanjang isterinya tidak terbukti telah berbuat nusyuz (Pasal 41 huruf (c) Undang-undang Perkawinan), dalam pemeriksaan cerai gugat.

b) Pengadilan Agama/ Mahkamah Syar'iyah sedapat mungkin berupaya untuk mengetahui jenis pekerjaan dan pendidikan suami yang jelas dan pasti dan mengetahui perkiraan pendapatan rata-rata perbulan untuk dijadikan dasar pertimbangan dalam menetapkan nafkah madhiyah, nafkah iddah dan nafkah anak, Cerai gugat dengan alasan adanya kekejaman 
atau kekerasan suami, Hakim secara ex officio dapat menetapkan nafkah iddah (lil istibra').

Berdasarkan ketentuan di atas, bahwa dalam perkara cerai talak maupun cerai gugat Hakim Pengadilan Agama/ Mahkamah Syar'iyah secara ex officio dapat menetapkan kewajiban nafkah iddah terhadap suami sepanjang isteri tidak terbukti nusyuz, dalam perkara cerai talak Hakim Pengadilan Agama/ Mahkamah Syar' iyah secara ex officio dapat menetapkan kewajiban mut'ah terhadap suami, akan tetapi dalam perkara cerai gugat tidak diatur demikian.

Kewajiban pemberian nafkah iddah dipertegas lagi dalam Pasal 152 KHI yang menyebutkan bahwa "Bekas isteri berhak mendapatkan nafkah iddah dari bekas suaminya kecuali ia nusyuz". Nafkah iddah adalah nafkah yang diberikan kepada suami pada masa waktu tunggu akibat perceraian. Iddah menurut penjelasan Muhammad Syaifuddin dkk (2014:401) adalah masa menunggu atau tenggang waktu sesudah jatuh talak dalam waktu dimana si suami boleh merujuk kembali isterinya, sehingga pada masa iddah ini si isteri belum boleh melangsungkan perkawinan baru dengan yang lain. Adapun tujuan dan kegunaan masa iddah yaitu:

1) Untuk memberi kesempatan berpikir kembali dengan pikiran yang jernih, setelah mereka menghadapi keadaan rumah tangga yang panas dan yang demikian keruhnya sehingga mengakibatkan perkawinan mereka putus.

2) Dalam perceraian karena ditinggal mati suami iddah diadakan untuk menunjukan rasa berkabung atas kematian suami.

3) Untuk mengetahui apakah dalam masa iddah tersebut pihak isteri telah mengandung atau tidak.
Ketentuan waktu tunggu diatur pada Pasal 153 KHI. Kewajiban suami untuk memberikan nafkah iddah akan gugur apabila istri dinyatakan nusyuz. Siti Ruhaini Dzuhayatin (2013:267) mengemukakan bahwa nusyuz berarti durhaka, atau ingkar dari kewajiban suami atau isteri. Nusyuz dapat berarti kebencian salah seorang diantara suami atau isteri kepada pasangannya. Oleh karena itu dalam hukum Islam nusyuz berlaku baik untuk pihak suami maupun isteri. Pengaturan tentang nusyuz dalam hukum positif diatur dalam Pasal 84 KHI, sebagai berikut :

1) Isteri dapat dianggap nusyuz jika ia tidak mau melaksanakan kewajibankewajiban sebagaimana dimaksud dalam pasal 83 ayat (1) kecuali dengan alasan yang sah.

2) Selama isteri dalam nusyuz, kewajiban suami terhadap isterinya tersebut pada Pasal 80 ayat (4) huruf a dan b tidak berlaku kecuali hal-hal untuk kepentingan anaknya.

3) Kewajiban suami tersebut pada ayat (2) di atas berlaku kembali sesudah isteri tidak nusyuz.

4) Ketentuan tentang ada atau tidak adanya nusyuz dari isteri harus didasarkan atas bukti yang sah.

Kewajiban istri sebagaimana dimaksud dalam Pasal 83 KHI adalah : 1) Kewajiban utama bagi seoarang isteri ialah berbakti lahir dan batin kepada suami di dalam yang dibenarkan oleh hukum Islam; 2) Isteri menyelenggarakan dan mengatur keperluan rumah tangga sehari-hari dengan sebaik- baiknya.

Islam juga mengatur kewajiban suami untuk memberikan nafkah iddah, firman Allah dalam al-Qur'an Surah Ath-Thalaq ayat 7, yang artinya: "Orang (para suami) yang mampu (berkewajiban) untuk memberi nafkah (termasuk nafkah iddah) menurut kemampuannya, dan 
orang (para suami) yang disempitkan rezkinya, hendaklah memberi nafkah dari harta yang diberikan Allah kepadanya".

Seorang perempuan yang dalam masa iddahnya talak $b a^{\prime}$ in dan dia dalam keadaan hamil maka dia berhak juga menerima nafkah belanja, pakaian dan tempat tinggal dari mantan suaminya sampai anaknya lahir. Ini berlandaskan dari firman Allah Swt dalam Qur'an Surat At-Thalaq Ayat 6 yang artinya: "Tempatkanlah mereka (para isteri) dimana kamu bertempat tinggal menurut kemampuanmu dan janganlah kamu menyusahkan mereka untuk menyempitkan (hati) mereka. Dan jika mereka (isteri-isteri yang sudah ditalak) itu sedang hamil, maka beri nafkahlah kepada mereka nafkahnya hingga mereka bersalin, kemudian jika mereka menyusukan (anak-anakmu) maka kepada mereka upahnya, dan musyawarahkanlah di antara kamu (segala sesuatu) dengan baik, dan jika kamu menemui kesulitan maka perempuan lain boleh menyusukan (anak itu) untuknya"

Fuqaha telah sepakat bahwa perempuan yang berada dalam masa iddah talak raj" $i$ masih berhak mendapat nafkah dan tempat tinggal.

\section{Pertimbangan Hukum Hakim dalam Pemberian Mut'ah dan Nafkah Iddah dalam Perkara Cerai Gugat}

Dalam putusan Nomor Perkara 0076/Pdt.G/2017/PA.Mgl, majelis hakim telah melakukan penemuan hukum (rechtsvinding) karena menurut hakim terkait dengan nusyuz belum diatur secara jelas dalam peraturan perundangundangan (Jamadi, Ketua Majelis Hakim). Majelis hakim berpendapat bahwa yang dimaksud nusyuz adalah ketidakpatuhan salah satu pasangan terhadap apa yang seharusnya dipatuhi dalam kerangka hak dan kewajiban masing-masing pasangan yang timbul akibat adanya ikatan perkawinan tersebut dan/ atau berpalingnya salah satu pasangan terhadap pasangan lain. Lebih sederhananya adalah tidak taatnya suami atau isteri kepada aturan-aturan yang telah diikat oleh perjanjian yang telah terjalin dengan sebab ikatan perkawinan tanpa alasan yang dibenarkan oleh syara'. Artinya nusyuz adalah pelanggaran suami atau isteri atas komitmen bersama dalam bentuk hak dan kewajiban yang lahir akibat adanya ikatan perkawinan, sebuah ikatan yang suci, kuat, dan sakral. Dengan demikian nusyuz bisa dilakukan oleh suami atau isteri tidak hanya melulu isteri saja. Berdasarkan fakta yang ditemukan isteri (penggugat) tidak memenuhi unsur-unsur dalam pengertian nusyuz, maka pengadilan berpendapat isteri tidak nusyuz, sebaliknya justru suami (tergugat) yang memenuhi unsur-unsur nusyuz sehingga dengan mendasarkan pada Pasal 41 huruf (c) UU No. 1 Tahun 1974 jo Pasal 149 huruf (a) dan (b) KHI dan Yurisprudensi Mahkamah Agung Nomor 137 K/AG/2007 tanggal6Februari 2008 dan Yurisprudensi Mahkamah Agung Nomor 02 K/AG/2002 tanggal 6 Desember 2003, maka secara ex officio (karena jabatannya) majelis hakim menghukum suami (tergugat) untuk memberikan mut'ah dan nafkah iddah terhadap penggugat selaku mantan isteri.

Hal senada juga diungkap Agus Miswanto (pakar hukum Islam), bahwa cerai gugat menurut konseptual fikih disebut sebagai khuluk, dalam bahasa Arab disebut Al-Khuluk maknanya melepas pakaian. Khuluk digunakan untuk istilah wanita yang meminta kepada suaminya untuk melepas dirinya dari ikatan pernikahan, dengan membayar sejumlah uang agar suami mentalaknya sehingga dia selamat dari beban perkawinan. Perceraian karena Khuluk suami tidak berhak merujuknya kembali, segala urusan bekas isteri berada di tanganya sendiri sebab ia telah menyerahkan sejumlah harta kepada bekas suami guna 
pelepasan dirinya itu. Oleh karena itu, status perceraian karena khuluk adalah sebagai talak $b a^{\prime}$ in bagi isteri. Suami yang telah mengkhuluk bekas isterinya tersebut boleh mengadakan akad nikah baru dengan bekas isterinya itu dengan rukun dan syarat lazimnya akad nikah. Perceraian karena talak $b a^{\prime}$ in isteri tidak mendapatkan nafkah dalam masa iddah. Hal ini sebagaimana pendapat Syafie $i$, Hambali dan Maliki bahwa perempuan yang dalam masa iddah talak ba'in dan dalam keadaan tidak hamil tidak berhak mendapatkan nafkah belanja, pakaian dan tempat tinggal. Namun demikian suami tetap berkewajiban dalam hal nafkah untuk pemeliharaan dan pendidikan anak. Ketentuan dalam Pasal 149 KHI telah sesuai dengan syariat Hukum Islam yang mengadopsi pendapat Syafi'i. Mayoritas masyarakat Indonesia menganut mazhab Syafi'iyah yang berpendapat bahwa kewajiban suami memberikan nafkah iddah kepada mantan isteri hanya berlaku pada talak raj'i. Talak raj'i adalah talak atas kehendak suami dan suami mempunyai hak rujuk selama dalam masa iddah. Pendapat ini berdasarkan hadist riwayat Ahmad dan An-Nasa'i yaitu "Perempuan yang berhak mendapat nafkah dan tempat tinggal (rumah) dari mantan suaminya apabila mantan suaminya itu berhak merujuk kepadanya". Terkait putusan pengadilan dalam perkara cerai gugat yang membebankan suami untuk membayar mut'ah dan iddah terhadap isteri merupakansalahsatubentukijtihadhakim dengan alasan kemanusiaan dan keadilan serta alasan bahwa isteri tidak terbukti nusyuz. Meskipun dalam KHI tidak diatur mengenai akibat hukum karena perceraian gugat, tetapi ini merupakan penemuan hukum baru dan merupakan ijtihad hakim sepanjang ada peraturan yang dapat dijadikan sebagai dasar, dalam hal ini Yurisprudensi Mahkamah Agung Nomor 137 K/AG/2007 dan Pasal 41 UUPerkawinan. Ijtihad hakim tersebut sependapat dengan madzhab Hanafi yang berpendapat bahwa perempuan itu berhak juga menerima nafkah belanja, pakaian dan tempat tinggal. Pendapat Hanafi berdasarkan pada QS. At-Thalaq ayat 6 yang artinya "Tempatkanlah mereka (para isteri) dimana kamu bertempat tinggal menurut kemampuanmu dan janganlah kamu menyusahkan mereka untuk menyempitkan (hati) mereka".

Berbeda dengan pendapat di atas, Imdad (hakim PA Magelang) mengemukakan bahwa Pasal 149 KHI tersebut khusus mengatur tentang akibat hukum perceraian karena talak. Perkara nomor 0076/Pdt.G/2017/PA.Mgl memang benar terbukti isteri tidak nusyuz namun dalam perkara tersebut yang mengajukan perceraian adalah isteri dimana dalam hukum normatifnya akibat dari perceraian gugat tidak diatur mengenai kewajiban suami memberikan mut'ah dan nafkah iddah. Pertimbangan hukum hakim yang merujuk pada Pasal 149 KHI tidak tepat jika diterapkan dalam perkara cerai gugat, karena normatifnya atau bunyi pasalnya jelas menyatakan "bilamana perkawinan putus karena talak, suami wajib", dalam hal ini Pasal 149 KHI khusus diterapkan dalam perkara cerai talak bukan perkara cerai gugat. Hakim secara ex officio menghukum tergugat untuk membayar kepada penggugat mut'ah dan nafkah iddah dalam perkara cerai gugat di luar permintaan penggugat atau tidak diminta oleh penggugat dalam petitumnya jatuhnya adalah ultra petita. Hak ex officio itu berangkat dari pintu yang telah dirumuskan oleh undang-undang. Batasan ex officio adalah kewenangan yang telah diberikan oleh undang-undang. Jadi kalau tidak ada pintu masuknya berdasarkan undang-undang maka jatuhnya adalah ultra petitum, dalam hal ini ultra petitum adalah melanggar ketentuan Pasal 178 ayat (3) HIR yang menyatakan bahwa hakim dilarang menjatuhkan keputusan atas perkara 
yang tidak dituntut, atau memberikan lebih daripada yang dituntut. Mengapa demikian karena hal ini menyangkut hukum perdata yang menyangkut hak pribadi, hak privat orang, jadi tidak boleh memberikan lebih daripada yang dituntut di luar yang telah diatur oleh undangundang meskipun karena alasan itikad baik hakim.

MenurutH.AbdulHalim Muhammad Sholeh, bahwa terkait dengan pemberian nafkah iddah secara ex officio kepada tergugat (mantan isteri) dalam perkara cerai gugat tidak tepat jika hanya didasarkan pada Pasal 149 huruf (b) KHI, karena secara tekstual Pasal 149 huruf (b) KHI tersebut menyebutkan bahwa "bilamana perkawinan putus karena talak, maka bekas suami wajib memberi nafkah, maskan dan kiswah kepada bekas isterinya selama dalam iddah, kecuali bekas isteri tersebut telah dijatuhi talak ba'in atau nusyus dan dalam keadaan tidak hamil". Berdasarkan teks Pasal 149 KHI tersebut sudah jelas suami diwajibkan memberikan nafkah iddah apabila perkara tersebut karena talak yang diajukan oleh suami. Talak disini dipahami dengan talak raj' $i$, hal ini berdasarkan frasa "karena talak, maka suami wajib". Berdasarkan Pasal 118 KHI akibat dari talak raj'i adalah suami berhak rujuk selama isteri dalam masa iddah. Perkara cerai talak raj'i ada kepentingan suami untuk rujuk dengan isterinya dalam masa iddah. Kata wajib disini sifatnya mengikat dan setiap perkara perceraian yang diajukan oleh suami dan isteri tidak terbukti nusyuz maka bekas suami wajib memberikan nafkah, miskan, dan kiswan kepada bekas isteri selama masa iddah. Berbeda halnya dengan talak ba'in, berdasarkan Pasal 119 ayat (1) KHI menjelaskan bahwa talak ba'in shughra adalah talak yang tidak boleh dirujuk tapi harus dengan akad nikah baru dengan bekas suaminya meskipun dalam iddah. Pasal 149 huruf (b) menyebutkan "kecuali talak bain atau nusyuz" maka dalam perkara cerai talak $b a^{\prime}$ in isteri tidak berhak mendapat nafkah iddah karena suami tidak ada kepentingan untuk rujuk, atau dalam perkara cerai talak raj'i yang terbukti isteri telah berbuat nusyuz mantan isteri juga tidak berhak mendapatkan nafkah iddah. Berdasarkan Pasal 149 KHI huruf (b) tersebut dapat dipahami bahwa hanya perkara cerai talak yang diajukan oleh suami yang mewajibkan suami untuk memberi nafkah iddah kepada mantan isteri yang terbukti tidak berbuat nusyuz, sedangkan dalam perkara cerai gugat tidak semua perkara cerai gugat mendapatkan nafkah iddah ketika isteri terbukti tidak nusyuz, tetapi hanya berdasarkan pertimbangan hakim secara ex officio boleh memberikan nafkah iddah tetapi sifatnya tidak wajib. Pertimbangan hakim secara ex officio ini berdasarkan pada Pasal 41 huruf (c) UU No. 1 Tahun 1974 yang menyatakan bahwa Pengadilan dapat mewajibkan kepada bekas suami untuk memberikan biaya penghidupan dan/atau menetukan suatu kewajiban bagi bekas istri.

Pemberian Mut'ah dan nafkah iddah dalam perkara cerai gugat berdasarkan pada Yurisprudensi dan Surat Edaran Mahkamah Agung Nomor 3 Tahun 2018 tentang Pemberlakuan Rumusan Hasil Rapat Pleno Kamar Mahkamah Agung Tahun 2018 sebagai Pedoman Pelaksanaan Tugas Bagi Pengadilan. Berdasarkan SE MA tersebut meskipun perceraian diajukan oleh isteri apabila dianggap oleh hakim isteri yang menggugat layak untuk mendapatkan mut'ah maka tetap mendapatkan mut'ah dengan alasan isteri telah mengabdi selama bertahuntahun kepada suami. Pasal 149 huruf (a) dan Pasal 158 KHI menyebutkan bahwa kewajiban suami memberikan mut'ah kepada isteri hanya apabila belum ditetapkan mahar bagi isteri $b a^{\prime} d a$ al dukhul dan perceraian itu atas kehendak suami, artinya apabila perkara cerai talak atau yang mengajukan perceraian adalah 
suami maka suami diwajibkan untuk memberikan mut'ah, akan tetapi kata wajib dalam pasal tersebut tidak menghalangi atau tidak berarti berbunyi melarang suami untuk memberikan mut'ah apabila perceraian tersebut diajukan oleh isteri. Apabila ketentuan atau syarat dalam Pasal 158 KHI tidak terpenuhi maka bukan berarti suami dilarang untuk memberikan mut'ah. Apabila hakim menganggap isteri layak untuk diberikan mut'ah maka dalam perkara cerai gugat isteri bisa mendapatkan mut'ah dengan pertimbangan hakim melihat duduk perkara dan pembuktian di persidangan.

Pemberian mut'ah dan nafkah iddah dalam perkara cerai gugat yang tidak diminta oleh penggugat dalam petitumnya meskipun menyimpangi Pasal 178 ayat (3) HIR namun tidak berarti melanggar asas ultra petita, hal ini didasarkan bahwa putusan perkara nomor 0076/Pdt.G/2017/PA.Mgl tersebut merujuk pada Yurisprudensi Mahkamah Agung Nomor 137 K/AG/2007 dan nomor $02 \mathrm{~K} / \mathrm{AG} / 2002$. Saat ini payung hukum terhadap pemberian mut'ah dan nafkah iddah dalam perkara cerai gugat lebih jelas dan dipertegas lagi yaitu adanya Surat Edaran Mahkamah Agung Nomor 3 Tahun 2018 sebagai pedoman bagi Hakim, maka isteri dalam perkara cerai gugat dapat diberikan mut'ah, dan nafkah iddah sepanjang tidak terbukti nusyuz". Apabila dalam ketentuan undang-undang tidak mengatur tentang sesuatu hal atau ketika hakim terpaksa harus menyimpangi teks undang-undang, putusan hakim harus berpedoman pada asas keadilan, kemanfaatan dan kepastian hukum.

Pelaksanaan Isi Putusan Atas Pemberian Mut'ah dan Nafkah Iddah Dalam Perkara Cerai Gugat

Apabila dalam perkara cerai gugat dalam amar putusannya berbunyi mengabulkan gugatan pengugat, menjatuhkan talak satu ba'in shugro tergugat kepada penggugat, menghukum tergugat untuk membayar kepada penggugat mut'ah dan nafkah iddah, namun pada saat pembacaan isi putusan tergugat tidak mau membayar kewajiban tersebut atau tergugat tidak hadir dalam pembacaan isi putusan maka putusan tersebut menjadi putusan yang illusoir (putusan hampa), putusan tersebut tidak dapat dilaksanakan. Tidak ada gunanya menghukum suami untuk memberikan mut'ah dan nafkah iddah, karena suami belum tentu mau melaksanakan isi putusan tersebut secara sukarela karena tidak akibat hukumnya (Imdad). Lain halnya dalam perkara perceraian karena talak berdasarkan rumusan Rakernas Mahkamah Agung suami yang belum bisa membayar kewajibannya sebagaimana tersebut dalam putusan, maka suami tersebut tidak dapat melaksanakan sidang ikrar talak. Dalam rangka pelaksanaan Perma Nomor 3 Tahun 2017 tentang pedoman Mengadili Perkara Perempuan Berhadapan dengan Hukum untuk memberi perlindungan hukum bagi hakhak perempuan pasca perceraian, maka pembayaran kewajiban akibat perceraian, khususnya nafkah iddah, mut'ah, dan nafkah madliyah, dapat dicantumkan dalam amar putusan dengan kalimat dibayar sebelum pengucapan ikrar talak. Ikrar talak dapat dilaksanakan bila isteri tidak keberatan atas suami tidak membayar kewajiban tersebut pada saat itu (ketentuan ini mengubah huruf C, angka 12 SEMA No. 3 Tahun 2015, in casu nafkah iddah, mut'ah, dan nafkah madliyah).

Menurut H. Abdul Halim Muhamad Sholeh, pemberian mut'ah dan nafkah iddah dalam perkara perceraian dalam pelaksanaannya jangan sampai bersifat illusoir (tidak dapat dilaksanakan), artinya dalam pemberian mut'ah dan nafkah iddah dalam perkara cerai gugat harus mempertimbangkan kehadiran pihak tergugat (mantan suami). Kehadiran tergugat dalam persidangan sangat penting untuk memeriksa penghasilan 
dan kemampuan suami dalam memberikan $m u t^{\prime} a h$ dan nafkah iddah, hal ini sebagai dasar pertimbangan hakim dalam menetapkan besarnya mut'ah dan nafkah yaitu dengan mempertimbangkan kemampuan suami dan uang belanja yang bisa diberikan juga dengan mempertimbangkan kriteria atau standar hidup layak atau patut bagi Penggugat. Ketidakpastian tergugat bersedia melaksanakan putusan secara sukarela atau tidak berakibat bahwa putusan tersebut dianggap illusoir atau tidak bisa dilaksanakan. Dasar putusan tersebut tidak illusoir adalah penetapan mut'ah dan nafkah iddah dalam perkara cerai gugat harus berdasarkan kehadiran tergugat dan hakim dalam menetapkan mut'ah dan nafkah iddah harus mempertimbangkan penghasilan dan kemampuan suami, sehingga diharapkan putusan tersebut dilaksanakan secara sukarela oleh tergugat. Apabila suami tidak hadir maka dalam perkara cerai gugat hakim tidak bisa secara ex officio menghukum tergugat untuk memberikan mut'ah dan nafkah iddah kepada penggugat (mantan isteri) karena penetapan mut'ah dan nafkah iddah harus didasarkan pada kehadiran tergugat.

Menurut Jamadi, pelaksanaan isi putusan atas pemberian mut'ah dan nafkah iddah adalah dilaksanakan di luar persidangan, dan tergugat melaksanakan isi putusan secara sukarela. Pelaksanaan putusan atas pemberian mut'ah dan nafkah iddah dalam cerai gugat masih terdapat problem dalam pelaksanaanya meskipun dalam pembacaan putusan dihadiri oleh penggugat dan tergugat, yaitu tidak adanya instrumen yang dapat memaksa tergugat untuk melaksanakan isi putusan sebagaimana pada perkara cerai talak. Berdasarkan Surat Edaran Mahkamah Agung Nomor 1 Tahun 2017 tanggal 19 Desember 2017 tentang Pemberlakuan Rumusan Hasil Rapat Pleno Kamar Mahkamah Agung Tahun
2017 sebagai Pedoman Pelaksanaan Tugas bagi Peradilan dalam perkara cerai talak dalam amar putusanya dapat dicantumkan dengan kalimat dibayar sebelum pengucapan ikrar talak. Ikrar talak dapat dilaksanakan bila isteri tidak keberatan atas suami tidak membayar kewajiban tersebut pada saat itu. Dengan demikian instrumen pelaksanaan putusan dalam cerai talak dapat dilaksanakan melalui ikrar talak. Berbeda dengan perkara cerai talak, dalam perkara cerai gugat sepanjang tidak ada permohonan eksekusi dari pihak tergugat (pihak yang kalah) maka dianggap bahwa putusan tersebut dilaksanakan secara sukarela oleh tergugat, karena dalam perkara cerai gugat tidak ada instrumen yang dapat memaksa tergugat untuk membayar mut'ah dan nafkah iddah yang telah diputuskan. Upaya hukum yang dapat ditempuh oleh penggugat apabila putusan tidak dilaksanakan secara sukarela oleh tergugat, adalah pihak penggugat mengajukan permohonan eksekusi sejumlah uang kepada Ketua Pengadilan Agama yang memutuskan perkara tersebut. Eksekusi pada dasarnya merupakan tindakan atau upaya paksa menjalankan putusan. Eksekusi baru dapat dilakukan jika pihak yang kalah tidak bersedia untuk menjalankannya secara sukarela (Pasal 200 (11) HIR dan 207 R.Bg.) terhadap putusan yang telah berkekuatan hukum tetap dan ada permohonan eksekusi dari pihak yang menang (penggugat). Penggugat dapat mengajukan permohonan eksekusi sejumlah uang dengan menjadikan salah satu aset termohon eksekusi untuk disita. Pemohon eksekusi harus memastikan bahwa aset termohon tersebut benarbenar dan pasti hak milik termohon, aset tersebut tidak berada di tangan pihak ketiga atau tidak sedang digunakan sebagai jaminan hutang pada bank atau lembaga keuangan lain, karena barang itulah yang nantinya akan digunakan 
untuk membayar atau melunasi mut'ah dan nafkah iddah yang tidak dibayarkan oleh tergugat kepada penggugat. Setelah pemohon (penggugat) mengajukan permohonan eksekusi maka Ketua Pengadilan Agama akan memberikan peringatan (aanmaning) kepada termohon eksekusi (tergugat). Jika dalam waktu 8 (delapan) hari setelah peringatan (aanmaning) termohon eksekusi belum melaksanakan isi putusan secara sukarela maka Ketua Pengadilan Agama membuat penetapan sita eksekusi atas objek termohon eksekusi lalu menjual aset tersebut melalui mekanisme lelang umum dan hasilnya dibayarkan kepada pemohon eksekusi (penggugat) sesuai jumlah yang ada pada putusan, sedangkan sisanya dikembalikan kepada termohon eksekusi. Pelaksana eksekusi adalah Panitera/ Jurusita yang ditunjuk oleh Ketua Pengadilan Agama.

Berdasarkan uraian di atas, bahwa pelaksanaan isi putusan atas pemberian mut'ah dan nafkah iddah dalam perkara cerai gugat adalah :

1) Pelaksanaan isi putusan perkara nomor 0076/Pdt.G/2017/PAMgl adalah di luar persidangan. Sepanjang tidak ada permohonan eksekusi dari pihak penggugat maka dianggap bahwa putusan tersebut dilaksanakan secara sukarela oleh tergugat di luar persidangan, apabila tergugat tidak melaksanakan isi putusan secara sukarela maka penggugat dapat mengajukan permohonan eksekusi sejumlah uang.

2) Kelemahan putusan pemberian mut'ah dan nafkah iddah dalam perkara cerai gugat adalah tidak adanya instrumen yang dapat memaksa tergugat untuk melaksanakan isi putusan sebagaimana pada perkara cerai talak. Pelaksanaan putusandalam cerai talak dapat dilaksanakan melalui sidang ikrar talak, sedangkan dalam perkara cerai gugat putusan dilaksanakan di luar persidangan. Sepanjang tidak ada permohonan eksekusi dari pihak tergugat (pihak yang kalah) maka dianggap bahwa putusan tersebut dilaksanakan secara sukarela oleh tergugat, karena dalam perkara cerai gugat tidak ada instrumen yang dapat memaksa tergugat untuk membayar mut'ah dan nafkah iddah yang telah diputuskan. Instrumen pemaksaan pelaksaan isi putusan dalam perkara cerai talak berdasarkan Surat Edaran Mahkamah Agung Nomor 1 Tahun 2017 tanggal 19 Desember 2017 tentang Pemberlakuan Rumusan Hasil Rapat Pleno Kamar Mahkamah Agung Tahun 2017 sebagai Pedoman Pelaksanaan Tugas bagi Peradilan dalam perkara cerai talak dalam amar putusanya dapat dicantumkan dengan kalimat dibayar sebelum pengucapan ikrar talak. Ikrar talak dapat dilaksanakan bila isteri tidak keberatan atas suami tidak membayar kewajiban tersebut pada saat itu, sedangkan dalam perkara cerai gugat tidak ada instrumen yang dapat memaksa tergugat untuk melaksanakan isi putusan.

3) Kelemahan putusan ini adalah karena tidak ada instrumen yang dapat memaksa tergugat untuk melaksanakan isi putusan maka ada kemungkinan tergugat tidak melaksanakan isi putusan secara sukarela. Apabila pihak yang kalah dalam hal ini pihak tergugat sulit menerima putusan dan enggan melaksanakan isi putusan secara sukarela maka pengajuan permohonan eksekusi merupakan upaya terakhir bagi pelaksanaan putusan pengadilan tersebut. Eksekusi merupakan proses yang cukup melelahkan bagi pihakpihak yang berperkara, selain menyita energi juga menyita biaya yang tidak sedikit, yang seringkali 
tidak sebanding dengan hak yang seharusnya di terima oleh penggugat berdasarkan putusan.

4) Ada perbedaan pendapat tentang apakah putusan perkara nomor 0076/Pdt.G/2017/PA.Mgl termasuk kategori illusoir atau tidak illusior. Jika didasarkan pada adanya spekulasi atau ada kemungkinan putusan tidak dilaksanakan secara sukarela, maka putusan tersebut dapat dikatakan sebagai putusan yang illusoir (putusan hampa) jika tidak dapat dilaksanakan karena tergugat belum tentu mau melaksanakan isi putusan. Namun demikian, putusan perkara nomor 0076/Pdt.G/2017/PA.Mgl tersebut dapat dikatakan tidak illusoir, hal ini didasarkan pada kehadiran Tergugat. Hakim telah memeriksa penghasilan dan kemampuan suami dalam memberikan mut'ah dan nafkah iddah, hal ini sebagai dasar pertimbangan hakim dalam menetapkan besarnya mut'ah dan nafkah yaitu dengan mempertimbangkan kemampuan suami dan uang belanja yang bisa diberikan juga dengan mempertimbangkan kriteria atau standar hidup layak atau patut bagi Penggugat, sehingga apabila putusan tersebut tidak dilaksanakan secara sukarela oleh tergugat, maka penggugat dapat menempuh upaya hukum dengan mengajukan permohonan eksekusi sejumlah uang.

\section{KESIMPULAN}

Pertimbangan hukum hakim dalam pemberian mut'ah dan nafkah iddah dalam perkara cerai gugat nomor 0076/ Pdt.g/2017/PA.Mgl adalah berdasarkan pasal 41 huruf (c) Undang-undang Nomor 1 Tahun 1974 jo pasal 149 huruf (a) dan (b) Kompilasi Hukum Islam dan Yurisprudensi Mahkamah Nomor 137 K/AG/2007 tanggal 6 Februari 2008 serta Yurisprudensi Mahkamah Agung RI
Nomor 02 K/AG/2002 tanggal 6 Desember 2003. Pertimbangan hukum hakim tersebut mengandung terobosan hukum (rule breaking) karena menyimpangi ketentuan Pasal 149 huruf (b) Kompilasi Hukum Islam. Pasal 149 KHI tidak mewajibkan suami untuk memberikan nafkah iddah bagi istri yang ditalak ba'in. Majelis hakim melakukan terobosan hukum dengan metode penemuan hukum (rechtsvinding) dengan berpedoman pada Pasal 10 ayat (1) dan Pasal 5 ayat (1) UU Nomor 48 Tahun 2009 tentang Kekuasaan Kehakiman yang menentukan bahwa hakim wajib menggali, mengikuti, dan memahami nilai-nilai hukum dan rasa keadilan yang hidup dalam masyarakat dalam memberikan putusan berkaitan dengan nusyuz karena nusyuz belum diatur secara jelas dalam peraturan perundang-undangan, hasilnya majelis hakim berpendapat nusyuz bisa dilakukan oleh suami atau isteri tidak hanya melulu isteri saja. Pengadilan berpendapat isteri tidak terbukti nusyuz, sebaliknya justru suami (tergugat) yang memenuhi unsurunsur nusyuz sehingga pengadilan secara ex officio menghukum suami (tergugat) untuk membayar mut'ah dan nafkah iddah kepada penggugat selaku mantan isteri. Kaidah hukum Yurisprudensi Mahkamah Nomor 137 K/AG/2007 tanggal 6 Februari 2008 adalah "Meskipun gugatan perceraian yang diajukan oleh isteri akan tetapi tidak terbukti isteri telah berbuat nusyuz, maka secara ex officio suami dapat dihukum untuk memberikan nafkah iddah kepada bekas isterinya dengan alasan bekas isteri harus menjalani masa iddah yang tujuannya antara lain untuk istibra' yang juga menyangkut kepentingan suami". Kata "dapat" dalam kaidah hukum tersebut dapat dipahami bahwa pemberian mut'ah dan nafkah iddah dalam perkara cerai gugat sifatnya tidak wajib, tidak semua perkara cerai gugat mendapatkan mut'ah dan nafkah iddah ketika isteri 
terbukti tidak nusyuz, tetapi hanya pada kasus-kasus tertentu dan hakim akan mempertimbangkan berdasarkan duduk perkara dan pembuktian di persidangan dalam pemberian mut'ah dan nafkah iddah dalam perkara cerai gugat.

Pemberian mut'ah dan nafkah iddah dalam perkara cerai gugat mengakomodasi pendapat madzhab Hanafi yang menyatakan bahwa perempuan itu berhak juga menerima nafkah belanja, pakaian dan tempat tinggal, kecuali perempuan itu beriddah karena perpisahan yang disebabkan oleh pelanggaran isteri, hal ini dengan berlandaskan pada firman Allah Swt QS. At-Thalaq ayat 6.

Penerapan hak ex officio hakim dengan menghukum suami untuk membayar mut'ah dan nafkah iddah kepada mantan isteri pada perkara 0076/Pdt.G/2017/ PAMgl tersebut menyimpangi ketentuan yang diatur pada Pasal 178 ayat (3) HIR/ Pasal 189 ayat (3), namun demikian putusan tersebut tidak melanggar asas ultra petita karena putusan tersebut hakim berdasarkan Yurisprudensi Mahkamah Agung RI Nomor 137 K/AG/2007 tanggal 6 Februari 2008 dan Nomor 02 K/AG/2002 tanggal 6 Desember 2003, bahkan saat ini pemberian mut'ah dan nafkah iddah dalam perkara cerai gugat diperkuat dengan adanya Surat Edaran Mahkamah Agung Nomor 3 Tahun 2018 tanggal 16 November 2018 tentang Pemberlakuan Hasil Rapat Pleno Kamar Mahkamah Agung Tahun 2018 sebagai Pedoman Pelaksanaan Tugas bagi Pengadilan.

Pelaksanaan isi putusan perkara nomor 0076/Pdt.G/2017/PAMgl adalah di luar persidangan. Sepanjang tidak ada permohonan eksekusi dari pihak penggugat maka dianggap bahwa putusan tersebut dilaksanakan secara sukarela oleh tergugat di luar persidangan, apabila tergugat tidak melaksanakan isi putusan secara sukarela maka penggugat dapat mengajukan permohonan eksekusi sejumlah uang. Dasar hukum pelaksanaan eksekusi sejumlah uang diatur dalam ketentuan Pasal 196 - Pasal 200 HIR/ Pasal 207 - Pasal 215 RBg.

Kelemahan putusan pemberian mut'ah dan nafkah iddah dalam perkara cerai gugat adalah tidak adanya instrumen yang dapat memaksa tergugat untuk melaksanakan isi putusan sebagaimana pada perkara cerai talak. Pelaksanaan putusan dalam cerai talak dapat dilaksanakan melalui sidang ikrar talak, sedangkan dalam perkara cerai gugat putusan dilaksanakan di luar persidangan. Kelemahan putusan ini karena tidak ada instrumen yang dapat memaksa tergugat untuk melaksanakan isi putusan maka ada kemungkinan tergugat tidak melaksanakan isi putusan secara sukarela. Apabila putusan tidak dilaksanakan secara sukarela maka upaya yang dapat ditempuh penggugat adalah dengan mengajukan permohonan eksekusi, di sisi lain eksekusi merupakan proses hukum yang cukup melelahkan bagi pihak-pihak yang berperkara, selain menyita energi juga menyita biaya yang tidak sedikit, yang seringkali tidak sebanding dengan hak yang seharusnya di terima oleh penggugat berdasarkan putusan.

\section{REFERENSI}

Asnawi, M. Natsir. 2016. Hukum Acara Perdata, Teori, Praktik dan Permasalahannya di Peradilan Umum dan Peradilan Agama. Yogyakarta : UII Press.

Harahap, M. Yahya. 2008. Hukum Acara Perdata: Tentang Gugatan, Persidangan, Penyitaan, Pembuktian, dan Putusan Pengadilan. Cet. VII. Jakarta : Sinar Grafika. 
Jamadi. 2018. Putusan Hakim Pengdilan Agama yang Progresif. Varia Peradilan Majalah Hukum Tahun XXXIII No. 387. Jakarta Pusat: Ikatan Hakim Indonesia.

Manan, Abdul. 2000. Penerapan Hukum Acara Perdata di Lingkungan Peradilan Agama. Jakarta : Yayaan Al-Hikmah.

Muthoifin. (2019). Shariah hotel and mission religion in surakarta indonesia. Humanities and Social Sciences Reviews, 7(4), 973-979. https://doi.org/10.18510/hssr.2019.74133

Muthoifin, S. shobron, \& Rahman, S. A. (2019). Humanist islam in indonesia ahmad syafii maarif perspective. Humanities $\mathcal{E}$ Social Sciences Reviews, 7(6), 780-786. https:/giapjournals.com/index.php/hssr/article/view/hssr.2019.76118/2384

Muthoifin, Pembinaan Kerukunan Masyarakat Baru Pada Perumahan Baru Perum Griya Salaam Boyolali, Proceeding of The URECOL, 12-15

Moelong, Lexy J. 2001. Metodelogi Penelitian Kualitatif. Bandung : Rosda Karya

Nuha,Muthoifin, Eternalisasi dan Kontekstualisasi Syair-Syair Imam Syafii Perspektif Pendidikan Islam, Proceeding of The URECOL UMP Purwokerto, 145-150

Soekanto, Soerjono dan Mamudji, Sri. 2013. Penelitian Hukum Normatif. Cetakan ke-15. Jakarta : Raja Grafindo Persada.

Sumitro, Roni Hanitio. 1982. Metodologi Penelitian Hukum. Semarang, : Ghalia Indonesia.

Undang-Undang Nomor 4 Tahun 2004 tentang Kekuasaan Kehakiman sebagaimana telah diubah dengan Undang-undang Nomor 48 Tahun 2009 tentang Kekuasaan Kehakiman.

Undang-Undang Nomor 7 Tahun 1989 tentang Peradilan Agama sebagaimana telah diubah dengan Undang-undang Nomor 3 Tahun 2006 tentang Perubahan atas Undang-Undang Nomor 7 Tahun 1989 tentang Peradilan Agama dan terakhir diubah dengan Undang-Undang Nomor 50 Tahun 2009 tentang Perubahan kedua atas Undang-Undang Nomor 7 Tahun 1989 tentang Peradilan Agama.

Undang-Undang Nomor 1 Tahun 1974 tentang Perkawinan.

Peraturan Pemerintah Republik Indonesia Nomor 9 Tahun 1975 tentang Pelaksanaan Undang-Undang Nomor 1 Tahun 1974 tentang Perkawinan.

Instruksi Presiden RI Nomor 1 Tahun 1991 tentang Kompilasi Hukum Islam.

Keputusan Ketua Mahkamah Agung Republik Indonesia Nomor : KMA/032/SK/ IV/2006 tentang Pemberlakuan Buku II Pedoman Pelaksanaan Tugas dan Administrasi Peradilan Agama Edisi Revisi Tahun 2013.

Surat Edaran Mahkamah Agung Nomor 1 tahun 2017 tentang Pemberlakuan Rumusan Hasil Rapat Pleno Kamar Mahkamah Agung Tahun 2017 sebagai Pedoman Pelaksanaan Tugas bagi Pengadilan.

Surat Edaran Mahkamah Agung Nomor 3 tahun 2018 tentang Pemberlakuan Rumusan Hasil Rapat Pleno Kamar Mahkamah Agung Tahun 2018 sebagai Pedoman Pelaksanaan Tugas bagi Pengadilan. 